\title{
Learning Process in Inclusive Primary School
}

\author{
Lanny Anggraini $^{1}$, Zulfiati Syahrial ${ }^{2}$, Robinson Situmorang ${ }^{3}$ \\ \{lanny.honey@gmail.com¹, zulfiati.syahrial@gmail.com², robinson.situmorang@gmail.com ${ }^{3}$ \}
}

Universitas Negeri Jakarta, Indonesia ${ }^{123}$

\begin{abstract}
The objectives of this research were describing: inclusive education learning process and the evaluation of learning outcome of special needs student. The methodology was using descriptive qualitative. Techniques of Collecting data were using interview, observation, and documentation study. The validity of instruments were using construct validity and technique of data analysis was using interactive model. Validity of data is done by triangulation data of techniques and resources. The results of the study that so far learning process in inclusive primary school was running quite good and there was no difference with the reguler school. The curriculum was national curriculum (Kurikulum tingkat Satuan Pendidikan) and Kurikulum 2013 with duplication model and little adjusment in subject matter and criteria of student outcome evaluation. The collaboration between classroom teacher and special teacher tutor (Guru Pembimbing Khusus) still poor. Therefore, the recommendation needed that should be synergized and collaboration among the government, the society and school for improving inclusive education, including assessment policy, socialization, training for the teachers, teachers for special education recruitment, and sharing best practice among them.
\end{abstract}

Keywords: Inclusive education, special needs student, regular student

\section{Introduction}

Inclusive education is an innovative educational system. It is a key strategy to reach Education for All (EFA) assuring all the learners can get education services. Inclusive education is an education system which provided to children with special needs who are educated together with other children in regular schools located in the area where they live to get support services and education in accordance with their needs and optimize their potential [1]. Recently many developing countries begun to implement inclusive education, supported by policies or regional statements. Indonesia is one of developing countries which launched these education system since 2003. Inclusive education policy in Indonesia is contained in Law No. 20 of 2003 article 15 about National education System, declared that education for children with special need is held by inclusive education or special education. The description of the Law was regulated in Regulation of the Minister of National Education Number 70 of 2009 about implementation of inclusive education in primary and secondary school. It is stated in Article 2 that inclusive education is an education system that provides education for all in the same school environment.

Population Census data from the Central Bureau of Statistics showed that the number of children with special needs in 2010 based on the type of disability for ages 10-14 years in the 
DKI Jakarta province is around 12,380 children (BPS, 2010). Until 2017, children with special need who attend inclusive primary school in DKI Jakarta province have only reached $13.34 \%$, so there are still around $86.66 \%$ of children who have not been served in inclusive schools (Kemdikbud, 2017). Nowdays implementation of Inclusive education still faced many problems. Based on the previous researched shown that implementation of inclusive education still have some problems like: (1) The method for assessing children with special need equated with other children; (2) Learning process in inclusive classroom were equated with reguler classroom (Sunarno, 2012); (3) Inadequate teacher competency [1]; (4) Lack of concern, low awareness and prejudices of other parents with regard to accepting students with special need in the same classroom as their mainstream children [2]; (5) Lack of facilities and infrastructures for students with special needs, etc. Based on some problems above, the researcher need to researched it deeply.

Based on the concept of special education, inclusive education is a combination of the implementation of special education with regular education in an education system. Whereas the definition of special education itself is an implementation of education for children with special needs such as children with physical, mental, intellectual disabilities, children who have social problems, and children who are gifted with special talents. Sapon-Shevin in Stainback stated that inclusive education is a system of educational services that requires all children with disabilities be served in the closest schools, in regular classes with their friends of the same age. Thus for regular schools that would be organized inclusive education, it needed school restructuring such as: availability of learning resources, supporting of all school ecosystem, including students, teachers, parents, and the surrounding community. Through this inclusive education, children with special needs are educated with other children in order optimizing their potential ( Stainback, 1992). Another definition was revealed by Mel Ainscow that inclusive school is a place to teach, learn, achieve, behave and prosper for all students. An effective school is an inclusive school in carrying out its education system, not only through its performance but also the work ethic of its citizens and their desire to provide equal opportunities to all students without exception (Ainscow, 2001). Sue Stubbs declared that inclusive education are: 1) wider than formal education, which includes homes, communities, non-formal and informal systems; 2) appreciate that all children can learn; 3) enabling structures, systems and methodologies to meet all children needs; 4) acknowledging and appreciating that every child has differences in age, sex, ethnicity, language, disability, socio-economic status, potential and ability; 5) is a dynamic process that evolves continuously in line with the cultural context; 6) is a strategy to advance and realize an inclusive society. These illustrated a model of inclusive education based on concepts about: children, the education system, diversity and discrimination, the process of advancing inclusion, and the concept of resources (Stubbs, 2008).

According to UNESCO, conceptually there have been differences and closed links between inclusive schools, inclusive education, and inclusive societies. Understanding and the links between them can be illustrated in Figure 1: 


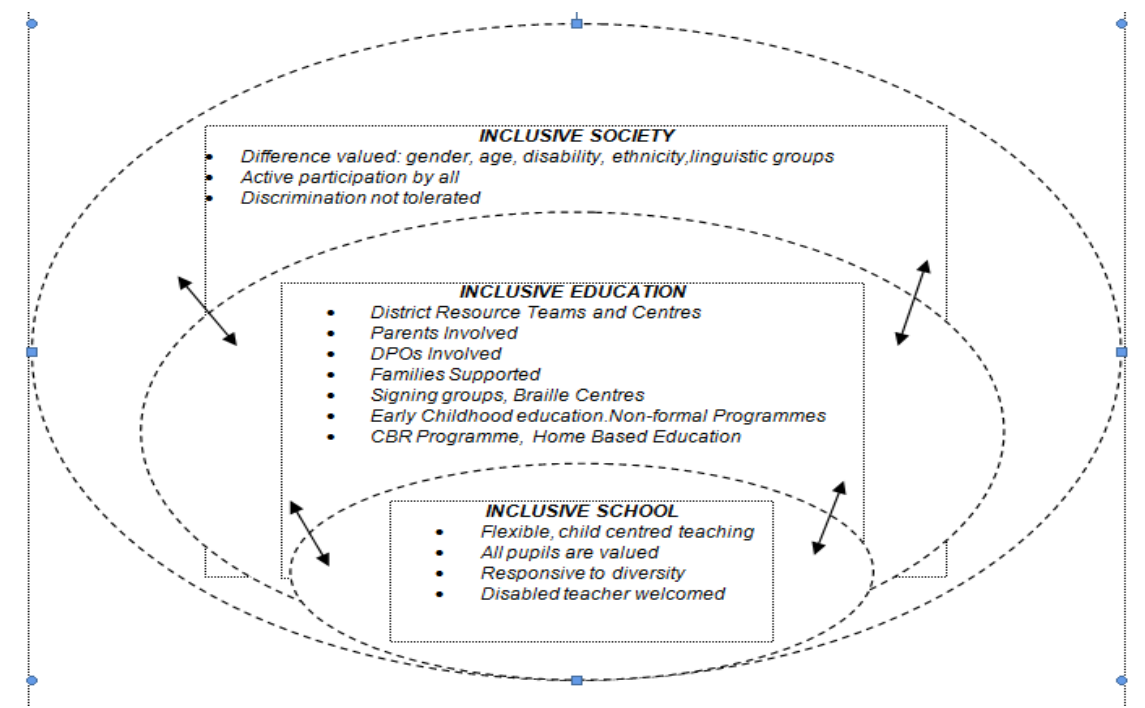

Fig. 1. The link between the Inclusive scholol, Inclusive Education, and Inclusive Communities according to UNESCO

In inclusive society there are difference valued such as: religion, race, ethnicity, regional language, normal children, children with special needs and those who are gifted, and so on. Inclusive society includes; family, kindergarten, school, class, place of work, and overall a community. They are placed where all children and adults are members of groups that interact and communicate with each other, help each other to learn and carry out their functions, hold each other in touch, recognize and accept different needs and activities, cooperate or partner in this society discrimination cannot be tolerated, all members of the community actively participate in creating an inclusive environment. The existence of an inclusive society, an inclusive education system can be created through policies made by the local government which of course involve parents, families, and communities that can be in the form of programs that support this inclusive education. Inclusive education is a system education intended for children with special needs to obtain appropriate education services held together with their peers in public schools so that eventually they become part of the community members of the school, thus creating a conducive learning atmosphere (Stubbs, 2008).

Inclusive school would increased student productivity, because they respected the needs of different students, involved students in the process of learning and teaching activities, prepared students for lifelong learning, and made partnerships with parents and holistic communities. Inclusive school is required to make adjustments from various aspects such as: curriculum, educational facilities, educators and education staff, assessment systems, and learning systems based on students need. Therefore in order to develop appropriate inclusive education programme, it needed anaccurate process of identification and assessment needs by professional personnel in their field. Learning characteristics in inclusive schools should be concerned some aspects, as follows: childrens' right in learning process,teacher competencies about inclusive education; non-discrimination, learning facilities, and appreciation of learning assignments. The objective of the study is to find out how is the learning process and learning outcomes of student with special needs. 


\section{Methodology}

The study was held in 2016-2017 at four inclusive primary schools in Jakarta province, such as: SDN Cempaka Putih Barat 16 Pagi Central Jakarta, SDN Menteng Atas 04 Pagi South Jakarta, SDN Marunda 02 Pagi North Jakarta, and SDN Palmerah 23 Pagi West Jakarta. It was selected by purposive random sampling. The methodology of the study was using descriptive qualitative. Techniques of Collecting data were using interview, observation, and documentation study. The validity of instruments were using construct validity. Instrument interview and observation were constructed about aspects were measured according to the relevant theory, then consulted with experts in inclusive education programs, with the results: without improvement, there are improvements, or totally overhauled. The questionnaire instrument was then tested and tabulated. The method used in assessing the validity of the questionnaire is product moment correlation (moment product correlation, Pearson correlation). Test reliability using the Cronbach Alpha method. Technique of data analysis was using interactive model Miles and Huberman which components of data analysis includes: data collection, data reduction, datadisplay, and conclusion drawing/verifying. Validity of data is done by triangulation data of techniques and resources. Triangulation involves the careful reviewing of data collected through different methods in order to achieve a more accurate and valid estimate of qualitative results for a particular construct (Allen, n.d., 2006). The datasets of this study could be access at https://osf.io/65rm $2 /$ from open science framework (OSF)[12]

\section{Result and Discussion}

The result of the study shown in the four schools, learning process in inclusive classroom were conducted quite well, as equal as reguler classroom. There was no special preparation before taching. Lesson plan was made by classroom teacher, Individual Education Programme (IEP) was made by special counselor only in three schools (SDN Cempaka Putih Barat 15 Pagi, SDN Marunda 02 Pagi, SDN Menteng Atas 04 Pagi). SDN Palmerah 23 Pagi didn't make IEP because it didn't have special conselor/special teacher tutor.Learning process was held in three steps, such as: apperception, core activity, and closing activity. Learning method was used only one or two methods. The Curriculum was used National Curriculum KTSP and Kurikulum 2013.Curriculum adjusment was full duplication. There were only adjusments in learning material and criteria of student outcome evaluation. Some adjustments was done by special conselor/special teacher tutor.Lerning media, subject material were used as equal as reguler classroom. Learning approach was tend to teacher centered. Interaction between teacher and students were very often and good. The students were very happy during the learning activity especially when they studied about science and art. Most of classroom teachers in four schools didn't know how to serve special need student. During the learning process, the teacher taught all the students were the same, unless if the special need students still didn't understand about the matter, the teacher exlained it again personally towards them. All the classroom teacher in four school didn't have any backgorund special education or how to serve special need students in reguler classroom. The teaching methods and media were chosen by them based on the purpose of the learning not students need and characteristic. But special conselor/special teacher tutor made IEP based on special student need and characteristic. The collaboration between parents and teacher were quite well unless in SDN Palmerah 23 Jakarta Barat was very poor. The parents will fasicilitated what the students need 
in order to help student easy to learn in the house, but the parent couldn't help the student during the learning process in the classroom. The collaboration between community and the teacher were still poor during the learning process.

Learning outcomes of student with special need in four schools were lower than reguler student. The student outcome evaluation as the same as the reguler. The teacher used written and oral test. The item test were multiple choice, essay, and fill in. But the criteria of the evaluation was different between them. 100 score for reguler student was different with 100 score for the special need student. Individual development of student with special need were quite good, more independent, social development were increasing very good, because the students with special need have alot of friends, special need student was easy to communicate and socialize with another common student. Students with special need were graduated $100 \%$ with some notes and continued to the next level, junior high school which conducted inclusive education or private junior high school. Still for the student form of student outcome report were the same as another common students, but there were some additional notes for the special need students which describing personal and social development progress from the special teacher tutor. But it was conducted only in three schools which has special teacher tutor, there were: SDN Cempaka Putih Barat 16 Pagi Central Jakarta, SDN Menteng Atas 04 Pagi South Jakarta, and SDN Marunda 02 Pagi North Jakarta.

\section{Conclusion}

Learning process in i nclusive primary school was conducted as equal as the reguler classroom. The adjusment only done by the special teacher tutor in subject matter and criteria student outcome evaluation. There weren't special preparation for lesson plan, selections of methods, approaches, materials, and learning media. Individual Education Programme was made by the special conselor/special teacher tutor. Learning outcomes of student with special need were lower than reguler student, but individual and social development of student with special need were well developed. Student with special need graduated $100 \%$ with some special notes about their development progress during the year, and they continued in reguler junior high school which conducted inclusive education or private school. Based on the result of the study, the recommendation are: that should be synergized and collaboration among the government, the society and school for improving inclusive education, including in-depth assessment policy, socialization, training for the teachers, teachers for special education recruitment, and sharing best practice among the schools, teachers, local governments.

\section{References}

[1] DJK, C., \& Balakrishnan, J.: Inclusive Education for Students with Intellectual Disability. Disability, CBR \& Inclusive Development. 23(2), pp.81-93 (2012)

[2] Ainscow, Mel. : Understanding the Development of Inclusive Schools: Some Notes and Further reading, pp. 726 (2001)

[3] Allen, D. (n.d.).,Oliver-Hoyo. : The Use of Triangulation Methods in Qualitative

Educational Research - Journal of College Science Teaching, pp. $42-48$ (2006)

[4] Fitria, R. : Proses Pembelajaran Dalam, 1, pp. 90-101(2012) 
[5] Kemdikbud. : Data Sekolah dan Siswa Inklusi, pp.1-2 (2017)

[6] Miles. Matthew B., \& A. Michael Huberman. : Analisis Data Kualitatif: Buku Tentang Metode- Metode Baru (Tejemahan), pp. 20 (1992)

[7] Peraturan Menteri Pendidikan Nasional Nomor 70 tentang Pendidikan Inklusif bagi Peserta Didik Berkelainan dan/atau peserta Didik dengan Potensi Kecerdasan dan Bakat Istimewa, pp.1(2009)

[8] Stainback, William. : Controversial Issues Confronting Special Education, pp. 69 (1992)

[9]Stubbs, Sue. : Inclusive education:where There Are Few Resources, pp.49 (2008)

[10] Sunarno. : Pengelolaan Pembelajaran Inklusi Di Sekolah Dasar (Studi Situs di Kecamatan Selo Kabupaten Boyolali, pp. 34 (2012)

[11] Undang-Undang Republik Indonesia Nomor 20 tentang Sistem Pendidikan Nasional, pp.7 (2003)

[12] S. R. Anggraini L, Syahrial Z, "Dataset of ' Learning Process in Inclusive Primary School."” [Online]. Available: https://osf.io/65rm $2 /$. 